\title{
Effect of Dietary Growth Promoters on Digestibility of Nutrients and Economical Efficiency of Growing Rabbits
}

\section{SA Abd EL-Latif*, AM Toson, HAM Elwan and Esraa S Helpawy}

Department of Animal Production, Faculty of Agriculture, Minia University, Minia, Egypt

*Corresponding Author: SA Abd EL-Latif, Department of Animal Production, Faculty of Agriculture, Minia University, Minia, Egypt.

Received: July 23, 2019; Published: August 13, 2019

DOI: 10.31080/ASNH.2019.03.0409

\begin{abstract}
The objective of this study was to investigate the effects of dietary turmeric powder, ginger powder, fenugreek seeds powder, dried lemon powder on digestibility of nutrients and economical efficiency of growing rabbits. A total of 30, New Zealand White rabbits (NZW) at 5 weeks of age were randomly assigned to five treatments with three replicates. The dietary treatments consisted of 5 groups as follows; the basal diet as control, phytogenic additives groups were supplemented with $0.5 \%$ turmeric powder, $0.5 \%$ ginger, $1.0 \%$ fenugreek seeds and $1.0 \%$ dried lemon added to the basal diet. At the end of the experimental period (12 weeks of age) nutrients digestion coefficient of the experimental diets were carried out. The data revealed that, the greatest ( $\mathrm{p} \leq 0.01$ ) value of DM, OM, CP, EE and NFE digestibility was considered for rabbits fed dietary fenugreek seeds. While, the lowest value of DM, OM and $\mathrm{CP}$ digestibility were reported for rabbits fed dietary curcuma compared with other dietary treatments. The data revealed that the greatest numerically net revenue, economical efficiency and relative economical efficiency (\%) was calculated for rabbits fed dietary lemon compared with rabbit groups fed other dietary supplementations.
\end{abstract}

Keywords: Rabbits; Growth Promoters; Economical Efficiency

\section{Introduction}

Modern intensive livestock and poultry production has achieved phenomenal gains in the efficient and economical production of high quality and safe animal products and by-products. Furthermore, the overall performance of livestock can be increased by improving nutrients utilization, health status, fertility and efficiency of production. The use of feed additives has been an important part of achieving efficient livestock production. Feed additives are non-nutritive substances, preparations and micro-organisms that are added to animal feed to improve productive, reproductive and health performances. Any substance is considered as a feed additive when, not having a direct utilization as nutrient, is included at an optimum concentration in diet to exert a positive action over the animal health status or the dietary nutrient utilization. Hutjens [1] defined feed additives as a group of substances that can cause a desired animal response in a non-nutrient role, such as $\mathrm{pH}$ shift, growth, or metabolic modifier. Feed additives are added deliberately to animal feed which may favorably influences characteristics of the animal feed, feed intake, gastro-intestinal flora, digestibility of the animal feeds, animal production, health, fertility and characteristics of animal products. Because of their chemical nature as active principles, additives are generally included in very small proportions in diet.
Global economic pressures have driven a tendency of the livestock production to produce more products per unit cost. This has led to changes to animal's environment like feeding, housing and disease control. Quality of feed nutrition is influenced not only by the content but also by some other aspects such as, feed presentation, hygiene, anti-nutritional factors, digestibility and palatability.

Feed additives provide a mechanism by which such dietary deficiencies can be addressed and also benefits not only associated with the nutrition and thus the growth rate of the animal concerned, but also its health and welfare. Antimicrobial growth promoters are commonly fed to animals to prevent disease and metabolic disorders, as well as improve feed efficiency. However, in recent years, public concern about the potential for antibiotic resistant strains of bacteria, the search for alternatives to replace antibiotics growth promoters has gained increasing interest in animal nutrition. The use of phytogenic feed additives has gained momentum for their potential role as natural alternatives to antibiotic growth promoters in animal nutrition. Compared with synthetic antibiotics or inorganic chemicals, these plant-derived products have proven to be natural, less toxic, residue free, and are thought to be ideal feed additives in food animal production. There are a large number of phytogenic feed additives which have antioxidant, antibacterial, anticoccidial, antiparasitic and anti-inflammatory effect [2]. 
The aim of this study was to evaluate the effect of adding some natural feed additives i.e. turmeric, ginger, fenugreek and dried lemon to rabbit diets at the levels of $0.5,0.5,1.0$, and $1.0 \%$ respectively, on digestibility of nutrients and economical efficiency.

\section{Materials and Methods \\ Experimental animals}

The present study was carried out at the farm of Animal and Poultry Production, Faculty of Agriculture, Minia University, Egypt during the period from March, 8 to April, 28, 2017. A total number of 30 males, 5 weeks old growing New Zealand white rabbits were used to study. Rabbits distributed into (5 treatments $\mathrm{x} 3$ replicates $\mathrm{x} 2$ rabbit $=30$ rabbits). All rabbits were housed in open house. The rabbits were allocated in a cage with slatted floor of iron. The dimensions of the cage were $(45 \times 45 \times 38 \mathrm{~cm})$ for length, width and high, respectively. Feed and water given to the rabbits ad-libitum during the experimental periods.

\section{Experimental diets}

Growing rabbits were distributed to five dietary treatment groups. The first group fed control diet formulated to contain adequate levels of nutrients for growing New Zealand White rabbits as recommended by the National Research Council [3]. The formulation and chemical composition of control diet is shown in table 1. Chemical analysis of ingredients and diets was determined according to AOAC [4]. Four additional dietary treatment groups were formulated to contain control diet incorporated with feed supplementation according to the source of addition such as $0.5 \%$ curcuma, $0.5 \%$ ginger, $1.0 \%$ fenugreek and $1.0 \%$ dried lemon respectively.

\begin{tabular}{|l|c|}
\hline \multicolumn{1}{|c|}{ Ingredients } & \% \\
\hline Ground yellow corn. & 54.0 \\
\hline Soyabean meal. & 20.3 \\
\hline Wheat bran. & 5.0 \\
\hline Limestone. & 0.3 \\
\hline Barseem hay. & 18.8 \\
\hline Dicalcium phosphate. & 1.0 \\
\hline Salt. & 0.3 \\
\hline Premix ${ }^{*}$ & 0.3 \\
\hline Total & 100 \\
\hline \multicolumn{1}{|c|}{ Calculated analyses\% } \\
\hline Crude protein, & 17.40 \\
\hline ME (Kcal/ kg) & 2561.70 \\
\hline Crude fiber, & 7.80 \\
\hline Calcium, & 0.68 \\
\hline Available phosphorus, & 0.33 \\
\hline Methionine+ cysteine, & 0.57 \\
\hline Lysine & 0.85 \\
\hline
\end{tabular}

Table 1: The composition and chemical analysis of the control diet for growing New Zealand White rabbits.

\section{Digestion trial}

Nutrients digestion coefficient of the experimental diets were carried out at the end of the experimental period (12 weeks of age). The rabbits were housed individually and fed the tested diets. The collection period lasted for 5 days. Feed intake was measured and feces output was collected daily. Hair and scattered feed were separated or taken out of the feces. The collected feces of each treatment was pooled together, and then dried at $60^{\circ} \mathrm{C}$ till constant weight. The dried feces for the successive five days were left few hours to get equilibrium with it in the atmosphere then, ground, well mixed and stored in screw-top glass jars for analysis. Digestion coefficient was calculated as follow:

Digestion coefficient $=\frac{\text { Digested nutrient }}{\text { Consumed nutrient }} \times 100$

Where, digested nutrient $=$ consumed nutrient - excreted nutrient fecal.

Proximate chemical analysis of basal diet and feces:

The chemical analysis was carried out at laboratory of Animal Production Department, Faculty of Agriculture and Minia University. Proximate chemical composition was determined according to A.O.A.C. methods [4]. Samples ground to fine powder using an electric grinder, placed in glass containers and sealed until time of analysis. Duplicate representative samples were analyzed for dry matter, crude protein, ether extract, crude fiber, and ash.

\section{Estimation of economic efficiency}

The economic efficiency of dietary treatments was estimated according to the prices of 2017 in Egyptian pound (LE). Economic evaluation for all experimental diets was calculated as the following steps for growing trails:

- Feed/gain ratio (a)

- $\quad$ Price/kg Feed (b) L.E.

- Feed cost of $1 \mathrm{~kg}$ weight gain $(\mathrm{a} \times \mathrm{b})$

- Market price of one kg live weight (c) LE

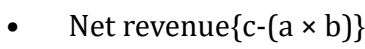

- Economical efficiency: $\frac{\text { Net revenue }}{\text { Feed cost }}$

- Relative economic efficiency \%= Economical efficiency of treatments Economical efficiency of control $\times 100$

Statistical analysis

Data were summarized using Microsoft ${ }^{\circledR} \quad$ Excel 2010 (10.2614.2625) Microsoft Egypt. The general liner model (GLM) was applied to test the differences among the five experimental groups. P-values less than 0.05 were considered to be statistically significant SAS Institute (2003). The statistical analysis was calculated using the following equation: 


\section{$\mathbf{Y i j}=\boldsymbol{\mu}+\mathbf{T i}+\mathbf{E} \mathbf{i j}$}

Where:

Yij = Experiment observations.

$\mu=$ The overall mean.

$\mathrm{Ti}=\mathrm{The}$ effect of dietary treatment.

$\mathrm{i}=\mathrm{T} 1,----\mathrm{T} 5$.

Eij $=$ The experimental error.

Duncan's test was used to examine the significance degrees among means [5].

\section{Results and Discussion}

Digestibility of nutrients

The digestibility of nutrients such as dry matter (DM), organic matter (OM), crude protein $(\mathrm{CP})$, crude fiber (CF), either extract (EE) and nitrogen free extract (NFE) data of dietary treatments are presented in Table 2. Results revealed that there was a highly significant difference $(\mathrm{p} \leq 0.01)$ in all previous parameters among all dietary treatments. The greatest $(\mathrm{p} \leq 0.01)$ value of $\mathrm{DM}, \mathrm{OM}, \mathrm{CP}, \mathrm{EE}$ and NFE digestibility was considered for rabbits fed dietary fenugreek seeds. While, the lowest value of DM, OM and CP digestibility were reported for rabbits fed dietary curcuma compared with other dietary treatments. Rabbits fed control diet recorded the lowest $(p \leq 0.01)$ value of CF digestibility. Hence, the greatest $(p \leq 0.01)$ value of $\mathrm{CF}$ digestibility was noticed when rabbits fed dietary ginger compared with other treatments.

\begin{tabular}{|l|c|c|c|c|c|c|}
\hline \multirow{2}{*}{$\begin{array}{c}\text { Treat- } \\
\text { ment }\end{array}$} & \multicolumn{6}{|c|}{ Digestibility of nutrients } \\
\cline { 2 - 7 } & DM & OM & CP & CF & EE & NFE \\
\hline Control & $83.00^{\mathrm{b}}$ & $83.66^{\mathrm{b}}$ & $72.27^{\mathrm{d}}$ & $66.45^{\mathrm{c}}$ & $96.10^{\mathrm{a}}$ & $85.75^{\mathrm{b}}$ \\
\hline $\begin{array}{l}\text { Curcu- } \\
\text { ma,0.5\% }\end{array}$ & $65.17^{\mathrm{e}}$ & $64.86^{\mathrm{d}}$ & $66.30^{\mathrm{e}}$ & $78.86^{\mathrm{ab}}$ & $90.99^{\mathrm{b}}$ & $66.93^{\mathrm{e}}$ \\
\hline $\begin{array}{l}\text { Ginger, } \\
0.5 \%\end{array}$ & $79.15^{\mathrm{d}}$ & $78.50^{\mathrm{c}}$ & $82.38^{\mathrm{b}}$ & $81.88^{\mathrm{a}}$ & $95.22^{\mathrm{a}}$ & $77.46^{\mathrm{d}}$ \\
\hline $\begin{array}{l}\text { Fenu- } \\
\text { greek, } \\
1.0 \%\end{array}$ & $90.03^{\mathrm{a}}$ & $88.41^{\mathrm{a}}$ & $90.66^{\mathrm{a}}$ & $77.11^{\mathrm{b}}$ & $97.51^{\mathrm{a}}$ & $88.02^{\mathrm{a}}$ \\
\hline $\begin{array}{l}\text { Lemon, } \\
1.0 \%\end{array}$ & $80.82^{\mathrm{c}}$ & $81.96^{\mathrm{b}}$ & $78.69^{\mathrm{c}}$ & $81.06^{\mathrm{ab}}$ & $96.61^{\mathrm{a}}$ & $83.07^{\mathrm{c}}$ \\
\hline $\begin{array}{l} \pm \text { SE } \\
\text { Sig. }\end{array}$ & 0.32 & 0.64 & 0.62 & 1.2 & 0.76 & 0.65 \\
\hline
\end{tabular}

Table 2: Effect of natural feed additives on digestibility of nutrients in growing rabbits.

a-eValues within the same column have different superscripts are significantly different $(p \leq 0.01)$. SE: standard error $( \pm)$.

$\left({ }^{* *}\right)$ : Highly significant $(\mathrm{P} \leq 0.01)$. DM: - Dry matter. OM: - Organic matter. CP: - Crude protein. CF: - Crude fiber. EE: - ethyl extract. NFE: - Nitrogen free extract.
Natural products of plant origin like spices, herbs and many plant extract can be considered as alternative to antibiotics as growth promoters in improving broiler performance [6]. Spices and herbs of various plants extract have appetizing and digestion stimulating property and antimicrobial affects $[7,8]$ concluded that herbs are valuable substitutes for health and nutrition in poultry industry. They can stimulate feed intake, the endogenous secretion, or may antibacterial, anticoccidial activities. A wide range of plant metabolites that belong to class isoprene derivatives, flavonoides and a large number of these compounds may act as antibiotics and antioxidants [9].

The improvement in the digestibility of nutrients as a result of adding fenugreek seeds to growing rabbits diet might be due to the presence of the fatty acids, or due to stimulating effect on the digestive system of broilers [6]. In addition, this improvement might be associated with an improved pattern of caecal fermentation; this effect is likely to be associated with the selective effect of saponin on bacteria/protozoa ratio, adaptation and quantity [10].

These findings were also in agreement with those of Elseed., et al. [10] fed growing rabbits on diet contained 0.0, 0.5 and 1 gm fenugreek saponins extract/day as feed supplementation. They stated that, dry matter digestibility of tested diets significantly $(\mathrm{P}<0.05)$ increased by adding the previous addition at all levels $(0.5$ and 1 gm), however crude protein digestibility was decreased.

Basavaraj., et al. [11] evaluated the digestibility of nutrients for growing rabbit fed diets contain $(0,150$, and 300 mg Turmeric Rhizoid Powder (TRP)/100g diet. They found that digestibility of dry matter, organic matter, nitrogen free extractives, neutral detergent fiber and acid detergent fiber was not altered by the supplementation of TRP in the diets of rabbit.

El-Faham., et al. [12] indicated that, feeding broiler chicks diet contain $0,0.5 \mathrm{~g} / \mathrm{kg}^{-1}$ from each of (cinnamon, turmeric, and ginger) and ascorbic acid at $200 \mathrm{mg} / \mathrm{kg}^{-1}$ the tested materials improved digestibility of crude protein and ether extract but those of other nutrients were unaffected.

\section{Economical efficiency}

The effects of dietary treatments on the economical efficiency of experimental diet (L.E, 2017) are presented in Table 3. The data revealed that the greatest numerically net revenue, economical efficiency and relative economical efficiency (\%) was calculated for rabbits fed dietary lemon compared with rabbit groups fed other dietary supplementations. Adding the previous feed supplementations to growing rabbits diet did not enhance the economical efficiency of diets compared with the control diet. 


\begin{tabular}{|c|c|c|c|c|c|}
\hline \multirow{2}{*}{ Items } & \multicolumn{5}{|c|}{ Treatment } \\
\hline & control & Curcuma $0.5 \%$ & Ginger $0.5 \%$ & Fenugreek 1.0\% & Lemon $1.0 \%$ \\
\hline Price of $1 \mathrm{~kg}$ of addition, LE & 0 & 40 & 60 & 16 & 80 \\
\hline $\begin{array}{l}\text { Price of } \\
\text { addition }\end{array}$ & 0 & 0.02 & 0.03 & 0.016 & 0.08 \\
\hline Price of $1 \mathrm{~kg}$ control diet, L.E & 3.71 & 3.71 & 3.71 & 3.71 & 3.71 \\
\hline Feed/ gain ratio $(\mathrm{a})$ & 4.8 & 5.06 & 5.63 & 6.18 & 4.67 \\
\hline Cost of $1 \mathrm{~kg}$ feed (b) L.E & 3.71 & 3.73 & 3.74 & 3.72 & 3.79 \\
\hline Feed cost of kg weight gain $\left(a^{*} b\right)$ & 17.81 & 18.87 & 21.06 & 22.98 & 17.69 \\
\hline Market price of $1 \mathrm{~kg}$ live weight (c) & 35 & 35 & 35 & 35 & 35 \\
\hline Net revenue (c-(a*b), L.E & 17.19 & 16.13 & 13.94 & 12.02 & 17.31 \\
\hline Economical efficiency & 4.63 & 4.32 & 3.73 & 3.23 & 4.57 \\
\hline Relative economical efficiency (\%) & 100.00 & 93.30 & 80.56 & 69.76 & 98.70 \\
\hline
\end{tabular}

Table 3: Effect of different dietary supplementation on economical efficiency.

The improvement in economical efficiency for rabbits fed control diet than others fed supplemented diet due to the increasing values of feed conversion of rabbits fed supplemented diet than control diet.

León., et al. [13] fed fattening rabbits from 35 to 40 days of age for 7 weeks to evaluate industrial dehydrated citrus levels $(0,15,20$ and $25 \%$ ) in pelleted diets. They reported that the cost of all feed consumed/animal slaughtered was 9 Cuban cents less $(\mathrm{P}<0.05)$ and that of the TRM 20 Cuban cents less with $20-25 \%$ citrus than the control in the fattening period.

\section{Conclusion}

From the present study, It could be concluded that supplemented growing rabbits diet with $0.5 \%$ turmeric powder, $0.5 \%$ ginger, $1.0 \%$ fenugreek seeds and $1.0 \%$ dried lemon as growth promoters improve digestibility of nutrients. However the additions did not improve economical efficiency.

\section{Acknowledgement}

Our deep thanks to all stuff members of the Department of Animal and Poultry Production for their assists to complete this work.

\section{Bibliography}

1. Hutjens M F. "Feed additives". Veterinary Clinics of North America: Food Animal Practice 7.2 (1991): 525-540.

2. Singh P K. "An Overview of Feed Additives. New India Publishing Agency, New Delhi - 110034, India”. Animal Feed Additives (2015): 1-13.

3. National Research Council (N R.C). "Nutrient Requirements of Poultry".9th rev. ed. Natl. Res.Counc, Natl. Acad. Press, Washington, DC (2004).

4. AOAC. "Official Methods of Analysis", 17th ed. Association of Official Analytical Chemists, Arlington, VA (2000).

5. Duncan D B. "Multiple ranges and multiple F-tests". Biometric 11.1 (1955): 1042.
6. Hernandez F., et al. "Influence of two plant extracts on broiler performance, digestibility and digestive organ size". Poultry science 83 (2004): 169-174.

7. Alcicek A., et al. "The effect of essential oil combinationderived from selected herbsgrowing wild in turkeyon broiler performance". South African Journal of Animal Science 33.2 (2003): 89-94.

8. Abdulmanan Chand N., et al. "Effect of periodic supplementation of herbal infusion on the liver function and lipid profile of broiler chicken". Sarhad Journal of Agriculture 28.1 (2012): 75-82.

9. Shin L., et al. "Use of Aloe vera yoghurt for acid production, viscosity, sensory properties and quality retention". Journal of Investigative Dermatology 102.2 (1995): 197-204.

10. Elseed A M., et al. "Effects of Fenugreek (Trigonella foenumgraecum) Seeds Saponin on Digestibility, N-Retention, Hematological Parameters and Blood Metabolites in Rabbits". World's Veterinary Journal 3 (2013): 65-73.

11. Basavaraj M., et al. "Effect of dietary supplementation of Pulvis Curcuma Longa on the voluntary feed intake, nutrient digestibility and growth performance of broiler rabbits under summer stress". Veterinary World 3.8 (2010): 369-372.

12. El-Faham A., et al. "Effect of using some natural feed additives to substitute antibiotic growth promoters on performance and blood parameters of broilers". Egypt Poultry Science 34.111 (2014): 735-750.

13. Leon R P De., et al. "Citrus Meal In Pelleted Diets For Fattening Rabbits". Cuban Journal of Agricultural Science 33 (1999): $157-164$

\section{Volume 3 Issue 9 September 2019} (C) All rights are reserved by SA Abd EL-Latif., et al. 